\title{
A Gift from the Buddhist Monastery: The Role of Buddhist Medical Practices in the Assimilation of the Opium Poppy in Chinese Medicine during the Song Dynasty (960-1279)
}

\author{
JOSE A. CANTON-ALVAREZ * \\ Needham Research Institute, 8 Sylvester Rd, Cambridge CB3 9AF, UK
}

\begin{abstract}
This paper aims to critically appraise the incorporation of opium poppy into medical practice in Song-dynasty China. By analysing materia medica and formularies, along with non-medical sources from the Song period, this study sheds light on the role of Chinese Buddhist monasteries in the process of incorporation of foreign plants into Chinese medicine. It argues that Buddhist monasteries played a significant role in the evolution of the use of opium poppy in Song dynasty medicine. This is because the consumption practices in Buddhist monasteries inspired substantial changes in the medical application of the flower during the Southern Song dynasty. While, at the beginning of Song dynasty, court scholars incorporated opium poppy into official materia medica in order to treat disorders such as huangdan 黃㾝 and xiaoke 消渴, as well as cinnabar poisoning, this study of the later Song medical treatises shows how opium poppy was repurposed to treat symptoms such as diarrhoea, coughing and spasms. Such a shift in the medical use of the poppy occurred after Chinese literati and doctors became acquainted with the role of the flower in the diet and medical practices of Buddhist monks across China. Therefore, the case study of the medical application of opium poppy during the Song dynasty provides us with insights into how the spread of certain practices in Buddhist monasteries might have contributed to the change in both professional medical practices and daily-life healthcare in local communities in that period.
\end{abstract}

Keywords: Chinese medicine, Opium poppy, Buddhism, Song dynasty, Dietetics, Literati

* Email address for correspondence: jacantonal@ gmail.com

This research was possible thanks to the generous support of the Jing Brand Scholarship in Chinese Science and Civilisation and the Needham Research Institute, Cambridge. This research has also benefited from the PhD research funding provided by the Confucius China Study Programme and the resources at Renmin University of China. Early versions of this paper were presented at the 9th International Congress on Traditional Asian Medicines (ICTAM IX), University of Kiel, as well as the 5th Young Scholars' Forum in Chinese Studies, Chinese University of Hong Kong. The author would also like to thank the anonymous reviewers for their insightful comments. 


\section{Introduction}

In 1186, Lu You 陸游 (1125-1210) was appointed to be Prefect of Yan prefecture 嚴州, nowadays part of Hangzhou. Being already sixty-one years old, it was Lu's last official appointment before retirement. ${ }^{1}$ In those years, he started to experience the first signs of old age, and he would usually fall sick in the winter. During his periods of convalescence, he would turn to poetry for solace. In one of the poems resulting from these diversions, entitled Disease compels me to write a long song to pass the time during a blizzard 病告中遇風雪作長歌排悶, Lu described his experience of coping with the crudeness of the winter:

The blizzard makes it impossible to go out, so I shut the windows and curtains to recuperate from my decrepit state. In the dusk, I hear [the wind] blowing on my window while I lie down and seek refuge from the cold in the rules of poetry. My grandson spreads a pleasant quilt, and my son offers me a piece of green felt, which is incomparably warm. When I set fire under the idle cauldron, [cracks] like tea sprouts form on its frosted surface when stirring it with my trembling fist. I set the fire, add taro and a pinch of salt, and dissolve honey in the opium poppy broth. ${ }^{2}$

During the coldest days of winter, when he was sick Lu You used to prepare a concoction that contained opium poppieswhen he was sickm, entitled Assorted proses about the lakes and mountains 湖山雜賦, he recorded how he became acquainted with this practice in 1178 while being the supervisor of the tea and salt trade in Fujian. During his stay in the region he used to visit local Buddhist temples, such as the one at Mount Mei 梅山寺, in the vicinity of what is nowadays Xiamen. On his way to the temple, the cold weather forced him to seek refuge in a hut, where a group of Buddhist monks dwelled. The monks offered $\mathrm{Lu}$ a cup of this opium poppy decoction. ${ }^{3}$ Years later, he would remember this beverage and prepare it during his winter stays in Shanyin 山阴, his natal village, and would even record his appreciation for it in the Inscription on the wall of the studio 題書齋壁:

We took turns to tell stories accompanied by music suitable for our mood, when a breeze of cold air opened a window. Stirring the poppies [in the cauldron] I accept the words of the monk, and plant bananas while listening to the sound of rain. [Those who know] secret recipes are not afraid of death, and I am not writing this for the sake of glory. Does the ruler know about the important matters [discussed] in this room? No wonder [he does not], as few enter these walls during the autumn. ${ }^{4}$

The inscription shows how Lu became very fond of this Buddhist decoction, which he considered a 'secret recipe' and which might have been ignored by those ruling the country. This beverage became one of Lu's most trusted remedies to endure the worst days of the winter and he would mention it in several of his poems, such as Miscellaneous chants 雜詠 ${ }^{5}$ and Winter night 冬夜. ${ }^{6}$ The most interesting of these poems, entitled Chant on the foodstuff of the village neighbours 戲詠鄉里食物示鄰曲, was written around 1200 and describes how some vegetables were introduced into the diet of the inhabitants of Shanyin because of their medical properties, opium poppy being one of them:

In the past, Shanyin used to be called the 'Little Island of the Immortals', where thousands of towers surround a green hill. As all the properties in the surroundings are marvellous, one can see that all the locals are rich and

${ }^{1}$ D.R. Jonker, 'Lu Yu', in Herbert Franke (ed.), Sung Biographies (Wiesbaden: Franz Steiner Verlag, 1976), 691-704.

${ }^{2}$ Qian Zhonglian 钱仲联 and Ma Yazhong 马亚中 (eds), Lu You quanji jiaozhu 陆游全集校注, vol. 3 (Hangzhou: Zhejiang jiaoyu chubanshe, 2011), 188-9. All translations in this article are those of the author.

${ }^{3}$ Ibid., vol. 5, 37.

${ }^{4}$ Ibid., vol. 3, 10.

5 Ibid., vol. 7, 403.

${ }^{6}$ Ibid., vol. 4, 38 . 
famous. The tea here is almost as good as the one from Beiyuan, and medical herbs and seedlings which enter our diet, exceed the platform of Heaven. ... Ground opium poppies garnish the soups, and mountain yams wrapped with damp cloths are roasted in slow fire. ${ }^{7}$

With these accounts, $\mathrm{Lu}$ You endowed us with a detailed picture of the consumption of opium poppy in late Song-dynasty China. Similarly, many twelfth-century scholars became acquainted with the medicinal use of opium poppy after observing its consumption in Buddhist monasteries. As a result, these literati incorporated the poppy into their diet because of its medical properties. In the long term, this practice reached wider communities, as seen in the case of Shanyin, where various different kinds of vegetables and plants were inserted in the local diet because of their prophylactic potential.

In a broader sense, these poems by Lu You also give us insights into the role of Buddhist institutions and official scholars in the spread of certain pharmacological practices from the monastic to the lay sphere during the Song dynasty. This paper investigates the medical use of opium poppy in order to illustrate the effect Chinese Buddhist institutions had on the official and civil approaches to healthcare at the time. ${ }^{8}$ In doing so, it engages with the existing studies on Buddhist influence in Chinese medicine. The existing scholarship has shed light on the importance of Indian Buddhism in the transmission of medical knowledge from India and its impact on Chinese medicine, particularly during the Tang dynasty, and has shown how such influence decreased during the Song period as result of the prevalence of local forms of Buddhism, such as the Chan school. ${ }^{9}$ In that sense, scholars agree that the contribution of Chan Buddhist institutions to medical practice during the Song was limited to their role in healthcare and famine-relief provision, due to the inefficiency of the official efforts in this matter. ${ }^{10}$ Yet, the literature has not considered the role of the interaction between the monastic and lay sphere resulting from this Buddhist beneficence in the transmission of certain medical practices. Using the opium poppy as a case study, this paper illustrates the influence of Buddhist medical practices in Chinese medicine and pharmacology during the Song, as it enabled the spread of the use of the flower among lay medical practitioners, prompting substantial changes in its application.

\footnotetext{
${ }^{7}$ Ibid., vol. 5, 307-8.

${ }^{8}$ For the sake of brevity, I use the term 'Buddhist' referring to its Chinese branches and not to Indian Buddhism.

${ }^{9}$ C. Pierce Salguero, Translating Buddhist Medicine in Medieval China (Philadelphia: University of Pennsylvania Press, 2014). Chen Ming 陳明, Zhongguo yiliao yu wailai wenhua 中古医疗与外来文化 (Beijing: Beijing daxue chubanshe, 2013), 364-404. Catherine Despeux (ed.), Médecine, religion, et société dans la Chine médiévale: Étude de manuscrits chinois de Dunhuang et de Turfan, 2 vols (Paris: Collège de France, Institut des Hautes Études Chinoises, 2010). Chen Ming 陳明, Yindu fanwen yidian 'yili jinghua' yanjiu 印度梵文醫典《醫理精華》研究 (Beijing: Zhonghua shuju, 2002). Chen Ming 陳明, “Yindu fanwen yidian "yaoli jinghua” yi qi Dunhuang Yutianwen xieben 印度梵文医典”药理精华"及其敦煌于阗文写本, in Dunhuang yanjiu 敦煌研究, 2000, no. 3, 115-27. Xue Gongchen 薛公忱 (ed.), Ru dao fo yu zhongyiyao xue 儒道佛与中医药学 (Beijing: Zhongguo shudian, 2002), 500-685. Ma Boying 马伯英 et al., Zhongwai yixue wenhua jiaoliu shi 中外医学文化交流史 (Shanghai: Shanghai Renmin Chubanshe, 1993), 113-55.

${ }^{10}$ Cai Chongbang, 'Medical and healthcare practices', in Zhu Ruixin et al. (eds), A Social History of Middle Period China: The Song, Liao, Western Xia and Jin Dynasties (Cambridge: Cambridge University Press, 2016), 497-502. Nathan Sivin, Health Care in Eleventh-Century China (Heidelberg: Springer, 2015), 141-6. Asaf Goldsmith, The Evolution of Chinese Medicine: Song Dynasty, 960-1200 (Cambridge: Cambridge University Press, 2009), 57-8. Joseph Needham, Lu Gwei-djen and Nathan Sivin, Science and Civilisation in China, Vol. 6: Biology and Biological Technology, Part VI: Medicine (Cambridge: Cambridge University Press, 2000), 57. Chi-chiang Huang, 'Elite and clergy in northern Sung Hang-chou', in Peter N. Gregory and Daniel E. Gets Jr (eds), Buddhism in the Sung (Honolulu: University of Hawaii Press, 1999), 326. Wolfram Eberhard, A History of China (Berkeley: University of California Press, 1977), 216-19.
} 
In order to show the porousness of the boundaries between elite and popular medicine, and between religious and medical knowledge during the period, this study utilises both medical and non-medical sources. With regard to the medical sources, I examined the references to opium poppy in over thirty medical treaties from the Tang and Song dynasties, which I list in Table 1. Apart from the official materia medica, this research focuses especially on over twenty Song-dynasty non-official medical treaties, which were compiled by local doctors across China. These abundant sources provide us with a clear picture of changes in the Chinese physicians' understanding of the properties of opium poppy at the time. ${ }^{11}$ Also, unlike official sources, these treatises endow us with valuable information about the medical use of the poppy, such as the location where it was used or the context in which particular recipes were encountered. Alongside these medical sources, I also utilised accounts by literati of the period in order to investigate the transmission of the medical use of opium poppy. For this paper, I looked into the works of fourteen literati in order to unveil how they became acquainted with the medical use of the flower and the reasons why they consumed it. In that sense, they provide us with relevant information about the consumption of the flower in the Buddhist context, and how it may have influenced the medical practices of lay communities around China. These sources are also relevant because they comprise some of the most valuable accounts on the connections between Buddhism and daily life in Song-dynasty China. ${ }^{12}$ By combining these different sets of sources, I provide a nuanced account of the assimilation of the flower into Chinese medicine; one which highlights the role of Chan Buddhist medical practices in Song medicine.

This paper is divided in three sections. The first section explains how the opium poppy was used during the Tang and early Song dynasties, and how physicians of the time integrated its medical use into official materia medica around the treatment of disorders such as huangdan 黃疸 and xiaoke 消渴. In the second section, I show how the eleventhcentury scholars encountered medicinal use of the poppy in Buddhist monasteries around China, and how it influenced the communities around these monasteries and beyond. Finally, the third part illustrates how the transfer of the medicinal use of opium poppy from these monasteries to the lay sphere affected medical practice in China during the Southern Song dynasty. This influence seems to have been instrumental in a comprehensive shift towards the medical application of opium poppy in the treatment of diarrhoea, coughing and spasms during the Southern Song dynasty. ${ }^{13}$ By exploring these areas, this study will show how the transmission of the medicinal use of the poppy in Buddhist monasteries was crucial in the assimilation of the flower into medical practice in Song-dynasty China.

\footnotetext{
${ }^{11}$ Shang Zhijiun 尚志钧, Lin Ganliang 林乾良 and Zheng Jinsheng 郑金生 (eds): Lidai zhongyao wenxian jinghua 历代中药文献精华 (Beijing: Kexue jishu wenxian chuabnshe, 1989), 44-57. Paul Unschuld, Medicine in China: A History of Ideas (Berkeley: University of California Press, 1985), 167. Paul U. Unschuld. Medicine in China: A History of Pharmaceutics (Berkeley: University California Press, 1986), 53-83.

12 Mark Halperin, Out of the Cloister: Literati Perspectives on Buddhism in Sung China, 960-1279 (Cambridge, MA: Harvard University Asia Center, 2006). Frederick W. Mote, Imperial China 900-1800 (Cambridge, MA: Harvard University Press, 2003), 370-4.

${ }^{13}$ Incidentally, some of these latter applications are cross-culturally found and can be demonstrated to have a physiological basis. Richard Seymour and David E. Smith, The Physician's Guide to Psychoactive Drugs (New York: Routledge, 2011): 4-5. Enno Freye and Joseph V. Levy, Opioids in Medicine: A Comprehensive Review on the Mode of Action and the Use of Analgesics in Different Clinical Pain States (The Netherlands: Springer, 2008), passim.
} 


\begin{tabular}{|c|c|c|c|}
\hline Author & Chinese Title & English Title & Date \\
\hline $\begin{array}{l}\text { Chen Cangqi } \\
\text { 陳藏器 }\end{array}$ & $\begin{array}{l}\text { Bencao shiyi } \\
\text { 本草拾遺 }\end{array}$ & $\begin{array}{l}\text { Compilation of Omissions in the Materia } \\
\text { Medica }\end{array}$ & 739 \\
\hline $\begin{array}{l}\text { Lu Duoxun } \\
\text { 盧多遜 }\end{array}$ & $\begin{array}{l}\text { Kaibao bencao } \\
\text { 開寶本草 }\end{array}$ & Materia Medica of the Kaibao Era & 974 \\
\hline $\begin{array}{l}\text { Wang Huaiyin } \\
\text { 王怀隐 }\end{array}$ & $\begin{array}{l}\text { Taiping shenghui fang } \\
\text { 太平聖惠方 }\end{array}$ & $\begin{array}{l}\text { Prescriptions Collected by Imperial Favour } \\
\text { in the Taiping Era }\end{array}$ & 992 \\
\hline $\begin{array}{l}\text { Su Song } \\
\text { 蘇頌 }\end{array}$ & $\begin{array}{l}\text { Bencao tujing } \\
\text { 本草圖經 }\end{array}$ & Illustrated Materia Medica & 1062 \\
\hline $\begin{array}{l}\text { Kou Zongshi } \\
\text { 寇宗同 }\end{array}$ & $\begin{array}{l}\text { Bencao Yanyi } \\
\text { 本草衍义 }\end{array}$ & Materia Medica of Elucidated Meanings & 1116 \\
\hline $\begin{array}{l}\text { Wang Kuang } \\
\text { 王貺 (?) }\end{array}$ & $\begin{array}{l}\text { Quansheng zhimi } \\
\text { fang } \\
\text { 全生指迷方 }\end{array}$ & $\begin{array}{l}\text { Formulae for Guiding the Lost throughout } \\
\text { Life }\end{array}$ & c. 1125 \\
\hline $\begin{array}{l}\text { Zhao Jiqi } \\
\text { 趙佶敕 }\end{array}$ & $\begin{array}{l}\text { Shengji zonglu } \\
\text { 聖濟總錄 }\end{array}$ & $\begin{array}{l}\text { Comprehensive Index of Recipes } \\
\text { Sanctioned by the Emperor }\end{array}$ & c. 1127 \\
\hline $\begin{array}{l}\text { Xu Shuwei } \\
\text { 許叔微 }\end{array}$ & $\begin{array}{l}\text { Puji benshi fang } \\
\text { 普濟本事方 }\end{array}$ & $\begin{array}{l}\text { Fact-based Formulae for Common } \\
\text { Remedies }\end{array}$ & c. 1132 \\
\hline $\begin{array}{l}\text { Zhang Rui } \\
\text { 張鋭 }\end{array}$ & $\begin{array}{l}\text { Jifeng puji fang } \\
\text { 雞峰普濟方 }\end{array}$ & Formulae of Common Recipes from Jifeng & c. 1133 \\
\hline $\begin{array}{l}\text { Liu Fang } \\
\text { 劉昉 }\end{array}$ & $\begin{array}{l}\text { Youyou xinshu } \\
\text { 幼幼新書 }\end{array}$ & New Book of Paediatrics & c. 1150 \\
\hline $\begin{array}{l}\text { Xu Shuwei } \\
\text { 許叔微 }\end{array}$ & $\begin{array}{l}\text { Leizheng puji benshi } \\
\text { fang suji } \\
\text { 類証普濟本事方續 } \\
\text { 集 }\end{array}$ & $\begin{array}{l}\text { Assorted Extension to Fact-Based Formulae } \\
\text { for Common Remedies }\end{array}$ & c. 1154 \\
\hline $\begin{array}{l}\text { Wang Jixian } \\
\text { 王繼先 }\end{array}$ & $\begin{array}{l}\text { Shaoxing bencao } \\
\text { 紹興本草 }\end{array}$ & Materia Medica of the Shaoxing Era & 1157 \\
\hline $\begin{array}{l}\text { Hong Zun } \\
\text { 洪遵 }\end{array}$ & $\begin{array}{l}\text { Hongshi jiyan fang } \\
\text { 洪氏集驗方 }\end{array}$ & $\begin{array}{l}\text { Collection of Effective Formulae by Mr. } \\
\text { Hong }\end{array}$ & 1170 \\
\hline $\begin{array}{l}\text { Liu Wansu } \\
\text { 劉完素 }\end{array}$ & $\begin{array}{l}\text { Huangdi suwen } \\
\text { xianming lunfang } \\
\text { 黃帝素問宣明論方 }\end{array}$ & $\begin{array}{l}\text { Treatises and Formulae for the } \\
\text { Dissemination of the Yellow Emperor's } \\
\text { Basic Questions }\end{array}$ & c. 1172 \\
\hline $\begin{array}{l}\text { Chen Yan } \\
\text { 陳言 }\end{array}$ & $\begin{array}{l}\text { Sanyin jiyi bingzheng } \\
\text { fanglun } \\
\text { 三因極一病証方論 }\end{array}$ & $\begin{array}{l}\text { Discourse on Diseases, Diseases Signs and } \\
\text { Formulae Related to the Unification of the } \\
\text { Three Causes }\end{array}$ & 1174 \\
\hline $\begin{array}{l}\text { Yang Tan } \\
\text { 楊倓 }\end{array}$ & $\begin{array}{l}\text { Yang shi jiacang fang } \\
\text { 楊氏家藏方 }\end{array}$ & $\begin{array}{l}\text { Formulae Preserved in the Family of Mr. } \\
\text { Yang }\end{array}$ & 1178 \\
\hline $\begin{array}{l}\text { Wu Yankui } \\
\text { 吳彦奬 }\end{array}$ & $\begin{array}{l}\text { Chuanxin Shiyong } \\
\text { fang } \\
\text { 傳信適用方 }\end{array}$ & $\begin{array}{l}\text { Suitable Formulae, Transmitted with } \\
\text { Verification }\end{array}$ & 1180 \\
\hline $\begin{array}{l}\text { Wang Shuo } \\
\text { 王碩 }\end{array}$ & $\begin{array}{l}\text { Yijian Fang } \\
\text { 易簡方 }\end{array}$ & Formulae of Simple Remedies & c. 1195 \\
\hline $\begin{array}{l}\text { Wang Qiu } \\
\text { 王璆 }\end{array}$ & $\begin{array}{l}\text { Shizhai baiyi } \\
\text { xuanfang } \\
\text { 是齋百一選方 }\end{array}$ & $\begin{array}{l}\text { One Hundred and One Selected Formulae } \\
\text { by [Wang] Shizhai }\end{array}$ & c. 1196 \\
\hline $\begin{array}{l}\text { Liu Xinfu } \\
\text { 劉信甫 }\end{array}$ & $\begin{array}{l}\text { Huoren shizheng fang } \\
\text { houji } \\
\text { 活人事證方後集 }\end{array}$ & $\begin{array}{l}\text { Second Volume of Formulae for Saving } \\
\text { People's Lives Based in Proven Events }\end{array}$ & c. 1216 \\
\hline $\begin{array}{l}\text { Wang Zhizhong } \\
\text { 王執中 }\end{array}$ & $\begin{array}{l}\text { Zhenjiu zisheng jing } \\
\text { 針炎資生經 (1220) }\end{array}$ & $\begin{array}{l}\text { Classic of Supporting Life with } \\
\text { Acupuncture and Moxibustion }\end{array}$ & 1220 \\
\hline $\begin{array}{l}\text { Zhang Gao } \\
\text { 张杲 }\end{array}$ & $\begin{array}{l}\text { Yi shuo } \\
\text { 醫説 }\end{array}$ & Medical Anecdotes & 1224 \\
\hline
\end{tabular}

Table 1: Continued on next page. 


\begin{tabular}{|c|c|c|c|}
\hline $\begin{array}{l}\text { Chen Yan } \\
\text { 陳衍 }\end{array}$ & $\begin{array}{l}\text { Baoqing bencao } \\
\text { zhezhong } \\
\text { 寶慶本草折衷 }\end{array}$ & $\begin{array}{l}\text { Balanced Summary of the Materia Medica } \\
\text { of the Baoqing Era }\end{array}$ & 1227 \\
\hline $\begin{array}{l}\text { Chen Ziming } \\
\text { 陳自明 }\end{array}$ & $\begin{array}{l}\text { Furen daquan } \\
\text { liangfang } \\
\text { 婦人大全良方 }\end{array}$ & $\begin{array}{l}\text { Great Compilation of Gynaecological } \\
\text { Formulae }\end{array}$ & 1237 \\
\hline $\begin{array}{l}\text { He Daren } \\
\text { 何大任 }\end{array}$ & $\begin{array}{l}\text { Xiao'er weisheng } \\
\text { zongwei lunfang } \\
\text { 小兒衛生總微論方 }\end{array}$ & $\begin{array}{l}\text { Comprehensive and Subtle Treatises and } \\
\text { Formulae for Children's Healthcare }\end{array}$ & Early 13 th century \\
\hline $\begin{array}{l}\text { Yan Yonghe } \\
\text { 嚴用和 }\end{array}$ & $\begin{array}{l}\text { Yanshi jisheng fang } \\
\text { 嚴氏濟生方 }\end{array}$ & Formulae for the Benefit of Life by Mr. Yan & 1253 \\
\hline $\begin{array}{l}\text { Yang Shiying } \\
\text { 楊士瀛 }\end{array}$ & $\begin{array}{l}\text { Renzhai zhizhi } \\
\text { 仁齋直指 }\end{array}$ & $\begin{array}{l}\text { Straightforward Guide [to Formulae] of } \\
\text { [Yang] Renzhai }\end{array}$ & 1264 \\
\hline Unknown & $\begin{array}{l}\text { Chanbao zhufang } \\
\text { 産寶諸方 }\end{array}$ & Various Recipes of Obstetrics & 12th-13th century \\
\hline Various authors & $\begin{array}{l}\text { Taiping huimin heji } \\
\text { jufang } \\
\text { 太平惠民和劑局方 }\end{array}$ & $\begin{array}{l}\text { Prescription of the People's Benevolent } \\
\text { Pharmacy of the Taiping Era }\end{array}$ & 12th-13th century \\
\hline
\end{tabular}

Table 1: Index of medical sources quoted in this paper.

\section{The Beginnings of the Medical Use of the Opium Poppy in China: from Tang to Early Song Dynasties}

Opium poppy was introduced into China in the early Tang dynasty, as shown by several poems of the time. The earliest account of the opium poppy in Chinese sources can be found in a poem by Guo Zhen 郭震 (656-713) entitled Seed-bag flower 米囊花. ${ }^{14}$ As result of the trade relations along the Silk Route, the flower arrived in China from Central Asia, reaching regions such as Sichuan and Jiangnan during the eighth and ninth centuries, as proven by its appearance in the poems of Yong Tao 雍陶 (c.789-873) and Zhang Gu 張祜 (c. 785-c. 849). ${ }^{15}$ Nevertheless, medical sources of the period do not show that the Tang-dynasty doctors were aware of the medical properties of the opium poppy. In fact, the most prominent physicians of the time, such as Sun Simiao 孫思貌 (581-682), do not make any reference to the flower; ${ }^{16}$ neither does it appear in the most important medical treatises of the period, such as Yaoxing lun 藥性論 [On the Nature of Chemicals], Xinxiu bencao 新修本草 [New Corrected Materia Medica], Shiliao bencao 食療本草 [Materia Medica of Dietetics] or Shixing bencao 食性本草 [Materia Medica on the Nature of Food]. Concomitantly, it is not mentioned among the Buddhist texts regarding Indian pharmacology, transmitted to China during the Tang dynasty. ${ }^{17}$ Therefore, it is possible to infer that the medical use of the poppy was not one of the imports of Indian pharmacology, which arrived in China during that period through Buddhist texts.

\footnotetext{
${ }^{14}$ Mǐnáng huā was the earliest name for the flower in the Chinese language. Peng Dingqiu 彭定求 et al., 'Yuding quan Tang shi 御定全唐诗, in Jingying chizao tang siku quanshu guiyao 景印摛藻堂四庫全書薈要, vol. 431 (Taipei: Taiwan shijie shuju, 1988), 624.

15 Wang Bin 汪霖 et al., 'Peiwenzhai yongwu shixuan 佩文齋詠物詩選', in ibid., vol. 455, 294. Zhang Gu 張祜, Zhang Chengji Wenji 張承吉文集 (Shanghai: Shanghai guji chubanshe, 2013), 98.

${ }^{16}$ Wang Hongbin王宏斌, 'Yingsu zhuanru Zhongguo ji qi zai gudai de yiyao jiazhi xilun 罂粟传人中国及其在古代的医药价值析论, in Guangdong shehui kexue 广东社会科学, 2009, no. 5, 100..

17 The work of Chen Ming on the transmission of medical practices from India to China shows how opium poppy was not a part of such imports. Chen, op. cit. (note 9), passim. Xue, op. cit. (note 9), 544-54. Similarly, opium poppy is not mentioned in the pharmacological manuscripts found at Dunhuang. Catherine Despeux, 'Le recettes médicamenteuses de Dunhuang', in Despeux, op.cit. (note 7), vol. 1, 333-631.
} 
However, there is evidence pointing to a certain medical use of opium poppy in some localities in Northern China in Tang times. The opium poppy was included in Bencao shiyi 本草拾遺 [Compilation of Omissions in the Materia Medica] by Chen Cangqi 陳藏器 (687-757), yet Chen did not indicate any medical use for the flower; he just quoted a succinct description of it by an obscure Henanese author called Song Yangzi 嵩陽子 (?), ${ }^{18}$ which indicates that the flower was valued by certain communities in early Tang-dynasty Henan, perhaps because of its medical properties. This idea is consistent with the information found in later medical treatises. As can be seen from Su Song's 蘇頌 (1020-101) Bencao tujing 本草圖經 [Illustrated Materia Medica], there were some instances of medical use of opium poppy during the Tianbao era 天寶 (742-56). At that time, a doctor from Yingchuan prefecture 穎川, in Henan, presented a concoction to the court which contained dried poppies. ${ }^{19}$ According to $\mathrm{Su}$, the doctor argued that this recipe could treat the harm caused by heat 傷熱 which had led to the development of disorders such as yinhuang 陰黃 and huangdan 黄疸. It could also treat symptoms like severe chest pain 心頭氣痛, 繞心如刺, which proves that opium poppy was used as a painkiller at the time.

After the decline of the Tang dynasty, sources from the Five Dynasties and Ten Kingdoms period (907-60) endow us with a clearer picture of the consumption of opium poppy, either as food or as medicine. Written by the early Song historian Tao Gu 陶穀 (903-70), Qingyi lï 淸異錄 [Records of the Unworldly and the Strange] is a compulsory point of enquiry regarding the daily life of the court of the later Tang dynasty 後唐 (92337). Here, in the description of the war campaign of Li Siyuan 李嗣源 (867-933), for emperor Mingzong 唐明宗, we find a short description of how opium poppy served as an important food source when his army was faced with shortage of supplies:

When the Mingzong emperor went [to war] in the borders, he did not waste anything. So when he summoned his generals and subordinates to discuss matters [of the campaign], cups of 'Dharma milk beverage' 法乳湯 were prepared for everyone, which were garnished with opium poppy seeds simmered in water. ${ }^{20}$

This decoction of opium poppy seeds was also consumed by other members of the court, as shown by a poem compiled by late Qing dynasty scholar Shi Menglan 史夢蘭 (1812-98) in Quanshi gongci 全史宫詞 [Historical Collection of Palace Poetry]. The poem describes how, due to the shortages of supplies, the female servants in the court were instructed to have this 'Dharma milk beverage' as an evening meal. ${ }^{21}$ The name given to this brew indicates its Buddhist origin. Its consumption in the court could be explained by the fact that Buddhist monasteries during the Tang dynasty provided healthcare and beneficence to the public, ${ }^{22}$ which could have caused certain dietary habits from Buddhist

18 Shang Zhijun 尚志钧 (ed.), Bencao shiyi jishi 本草拾遗辑释 (Hefei: Anhui kexue jishu chubanshe, 2002), 317. According to the quote found in Bencao shiyi, in the entry about sour dates 酸霜, Song lived in the outskirts of what is nowadays Hua County 滑县 in Henan province: ibid., 379.

19 This reference in Bencao tujing can be found in the account about the 'beautiful spring herb' 麗春草, which Li Shizhen 李時珍 (1518-93) identified as the opium poppy in Bencao gangmu 本草綱目 [Systematic Materia Medica]. This was a local name for the flower around Henan province at the time. Su Song 蘇頌, Bencao tujing 本草圖經 (Hefei: Anhui kexue jishu chubanshe, 1994), 615-16. Li Shizhen 李時珍, Bencao gangmu 本草綱目 (Beijing: Renmin weisheng chubanshe, 1975), 960-1.

${ }^{20}$ Tao Gu 陶穀. 'Qingyi lü 清異錄, in Yinjing Wenyuange Siku Quanshu 印景文淵閣四庫全書, vol. 1047 (Taipei: Taiwan Shangwu Yinshuguan, 1986), 921-2.

${ }^{21}$ Shi Menglan 史夢蘭, Quanshi gongci 全史宫詞 (Beijing: Dacong wenyi chubanshe, 1999), 306.

22 Jacques Gernet, Buddhism in Chinese Society: An Economic History from the Fifth to the Tenth Centuries (New York: Columbia University Press, 1995), 217-28. Kenneth K.S. Ch'en, The Chinese Transformation of Buddhism (Princeton: Princeton University Press, 1973), 291-301. 
monasteries to reach lay communities, including the later Tang court. Eventually, such practices became useful during the Five Dynasties, a period when famine hit various warring states after the collapse of the Tang dynasty. ${ }^{23}$

Additionally, sources of the period indicate that the medical properties of opium poppy underpinned its consumption as a staple food and attracted the attention of certain doctors of the time. A recipe for 'opium poppy porridge' 罌粟䉼 was compiled in the book Nantang shiyi fang 南唐食醫方 [Dietary of the Southern Tang], arguably the only known medical source of the period. ${ }^{24}$ The recipe itself is the only proof of the existence of this dietary book, now lost, and was recorded by Su Song in Bencao tujing. ${ }^{25}$ According to the recipe, this porridge was made out of white poppies, ginseng and green taro, and helped to treat patients who were not able to ingest any food due to indigestion 療反胃不下 飲食. Further indication of the possible medical use of the poppy during this period can be inferred from A chant for opium poppy 詠罌粟子 by Zhu Zhenbai 朱貞白 (?). The poem describes the poppy as being similar to the Aristolochia debilis 鈴馬兒. According to Cheng Minsheng, the comparison of opium poppy with this plant proves that Zhu was aware of the medical properties of the poppy, as the A. debilis was commonly used in the treatment of severe coughing. ${ }^{26}$

These sources show how the consumption of opium poppy in post Tang-dynasty China was intimately related to a Buddhist context. Some aspects of these references to the consumption of the poppy are indicative of a possible Buddhist origin, such as the name of the 'Dharma milk beverage' consumed in the later Tang court or the fact that opium poppy was ingested through porridge. ${ }^{27}$ However, due to the lack of Buddhist medical sources from the period, it is impossible to clarify how Buddhist monks of the time became acquainted with the medical properties of opium poppy. ${ }^{28}$ I would argue that, in a context where diet and medicine were closely intertwined, certain communities in Northern China

\footnotetext{
${ }^{23}$ Naomi Standen, 'The five dynasties', in Denis Twitchett and Paul J. Smith (eds), The Cambridge History of China, vol. 5. Part One: The Sung Dynasty and Its Precursors, 907-1279 (Cambridge: Cambridge University Press, 2009), 99-100.

24 This work seems to have followed the developing interest in dietetics during the Tang dynasty, when this field became an important element in Chinese medical thought. Ute Engelhardt, 'Dietetics in Tang China and the first extant works of materia medica', in Elisabeth Hsu (ed.), Innovation in Chinese Medicine (Cambridge: Cambridge University Press, 2001), 173-91.

${ }^{25} \mathrm{Su}$, op. cit. (note 19), 610. Su did not compile any other recipe from Nantang shiyi fang in Bencao Tujing, which leads me to think that he considered this recipe as the only valuable or innovative recipe in the whole formulary. This supports the idea that, at least for Song-dynasty physicians, the consumption of opium poppy for medical purposes was perhaps the only worthwhile medical innovation of the Five Dynasties and Ten Kingdoms period.

${ }^{26}$ Cheng Minsheng 程民生, 'Songdai de yingsu 宋代的罂粟, in Guoji shehui kexue zazhi 国际社会科学杂志, 2016, no. 3, 205.

27 Between the Tang and Song, gruel became one of the main elements in Buddhist dietetics in medieval China. Chen Yuan-peng 陳元朋 and Kang Le 康樂, “Cong “biqiu shizhou” dao xiezhou yangshen 從<比丘食弹>到<喫 粥養生> ', in Conference on Religion and Medicine and the Second Meeting of the Asian Society for the History of Medicine 宗教與醫療學術研討會暨亞洲醫學史學會第二次年會 (Taipei, 2004). 37-49.

28 The only mentions of opium poppy in a Buddhist formulary appeared too late during the Song dynasty to be helpful in the case described here. There are three recipes compiled in Lingnan weisheng fang 嶺南衛生方 [Formulae for Life Preservation from Lingnan] by late-thirteenth-century Buddhist missionary Ji Hong 繼洪 (?). Ji wrote this formulary after his experience of treating patients with malaria in Lingnan region, incorporating in the process an earlier treatise, now lost, entitled Zhang lun 瘴論 [Treatise on Malaria], written by two early twelfth-century Southern Song scholars: Li Qiu 李璆 (?) and Zhang Zhiyuan 張致遠 (?). However, it is impossible to know whether these recipes belonged originally to Zhang lun or were added later by Ji Hong. Ji Hong 繼洪, Lingnan weisheng fang 嶺南衛生方 (Beijing: Zhongyi guji chubanshe, 1983), 118-24.
} 
started to use the poppy to treat some digestive disorders during the eighth century. ${ }^{29}$ By the early tenth century, such practices were distinctively perceived as Buddhist in certain circles, such as in the later Tang court, which indicates that the consumption of the poppy had been preserved in Buddhist monasteries. Indeed, Buddhist monks of the period were known for relying on the herbal medicine from the communities around them to complement their own, which could explain the transfer of this dietary habit into a Buddhist context. ${ }^{30}$ However, there are no further sources from the period that indicate whether the opium poppy was consumed in Buddhist monasteries at the time. In turn, court physicians developed an interest in the opium poppy and compiled its medical use in the official formulary of the later Tang dynasty, eg. Nantang shiyi fang. In any case, the information found in these sources does not indicate that opium poppy consumption during the period was significant, as the lack of evidence of this practice in the rest of the dynasties and states of this period suggests its localised use.

Nevertheless, Nantang shiyi fang started a tradition of official pharmacological sources compiling the medical use of the poppy, which would continue during the Song dynasty. These treatises provide us with insights into how Chinese physicians of the time developed medical uses for the flower. The first imperial materia medica of the Song dynasty, Kaibao bencao 開寶本草 [Materia Medica of the Kaibao Era], published in 974, included a succinct note about opium poppy, which describes that its seeds were mainly used to treat outbreaks of cinnabar poisoning, and it was consumed in a porridge cooked with bamboo juice. ${ }^{31}$ Similarly, in the first official formulary of the Song dynasty, Taiping shenghui fang 太平聖惠方 [Prescriptions Collected by Imperial Favour in the Taiping Era], the opium poppy was the main ingredient in a formula indicated to treat xiaoke resulting in heat 消渴熱, especially when causing patients to have a 'confused state of mind' 心神煩 亂. ${ }^{32}$ From these early descriptions of the opium poppy in Chinese sources, the one which appeared in Bencao Tujing by Su Song would be the most influential: ${ }^{33}$

\begin{abstract}
About opium poppy, the classics do not tell where it originates from, but nowadays it is found everywhere, as many families use it to decorate their gardens. It can be red or white and has a pungent smell. Its fruit looks like a bottle or an arrowhead, and stores tiny seeds inside. They are hard to cultivate. They must be planted during the ninth month, in a piece of land which was manured the year before. If not cultivated in this way, it will never germinate. One should wait until the fruits acquire a yellow colour before picking them. It is prescribed for improving the circulation of $q i$ and reducing fever. It cures nausea, phlegm in the chest and cinnabar poisoning. It is said that it can be cooked with bamboo juice to make porridge. It is a cold medicine and very good for the intestines. However, it is not advisable to consume it excessively, as it can alter the $q i$ in the bladder. ${ }^{34}$
\end{abstract}

These first records of opium poppy served as an introduction to the flower for later generations of physicians and set the foundations for its traditional medicinal use in China. However, this tradition did not necessarily result in a unified praxis, as different treatises would recommend it in the treatment of different disorders. The only exception would

\footnotetext{
${ }^{29}$ Needham et al., op. cit. (note 10), 78-84.

${ }^{30}$ Salguero has shown how the reconciliation of Indian and Chinese medicine was one of the most important tasks of Chinese translators of Buddhist medical texts since the sixth century. Salguero, op. cit. (note 9), 96120. Chinese herbal medicine was one of the few elements of the local medicine which, according to authors like Zhiyi 智顗 and other commentators, could be assimilated into Buddhist medical practice without risking a transgression of religious orthodoxy: ibid., 102-5.

${ }^{31}$ Lu Duoxun 盧多遜 et al., Kaibao bencao 開寶本草 (Hefei: Anhui kexue jishu chubanshe, 1998), 411.

32 Wang Huaiyin 王怀隐, Taiping shenhui fang 太平聖惠方, vol. 9 (Taipei: Xinwenfeng chuban gongsi, 1980), 5071-2.

${ }^{33} \mathrm{Su}$, op. cit. (note 19), 1-4. Unschuld, A History of Pharmaceuptics, op. cit. (note 11), 64-8.

${ }^{34} \mathrm{Su}$, op. cit. (note 19), 609-10.
} 
be the use of the opium poppy to treat an outbreak of cinnabar poisoning 丹石發動, which was recorded in official materia medica such as Kaibo bencao and Bencao tujing. Conversely, other major medical works of the early Song ignored any medical application of the poppy, as shown in materia medica of the period such as Bencao Yanyi 本草衍义 [Materia Medica of Elucidated Meanings] by Kou Zongshi 寇宗顛 (?). ${ }^{35}$ Similarly, early editions of the official Song formulary, Taiping huimin heji jufang 太平惠民和劑局方 [Prescription of the People's Benevolent Pharmacy of the Taiping Era], did not include any recipe using opium poppy. ${ }^{36}$ This situation would change drastically during the Southern Song dynasty, when a more unified use of the poppy in the treatment of diarrhoea, coughing and spasms became standard in medical literature of the period. Such change likely started after the consumption of opium poppy spread from Buddhist monasteries to lay communities around China in the late eleventh century.

\section{The Buddhist Connection: The Role of Buddhist Monks and Literati in the Spread of the Medical Use of Opium Poppy}

In order to shed light on how the medical use of opium poppy changed in Song-dynasty China, it is necessary to look beyond the medical sources from the early Song, into the accounts of the literati of the time. These sources provide indications of how the medical application of opium poppy to treat diarrhoea could have originated in Buddhist monasteries, from where it spread to lay communities. We find the earliest example of this in the work of Su Shi 蘇軾 (1037-1101). Su became acquainted with the consumption of opium poppy in 1085 in Yixing 宜興, a little village on the Western shore of Taihu lake in Changzhou, Jiangsu province. After he was granted retirement from official service, he moved to a small farm he had acquired in that locality, where he enjoyed the hospitality of the monks at the Zhuxi temple 竹西寺. ${ }^{37} \mathrm{He}$ paid homage to this temple in three short poems entitled Comments on my visit to Zhuxi temple after returning to Yixing 歸宜興留 題竹西寺, the second of which describes how:

The monks convinced me to drink a betony decoction, while the lads boiled some opium poppies. Then I borrowed a rattan bed and a pillow, not wanting to be unworthy of the cool air blowing among the bamboo trees. ${ }^{38}$

This poem stands as the earliest evidence of opium poppy consumption for medical purposes in a Buddhist temple. The monks in Yixing consumed opium poppies along with a decoction of betony (Stachys japonica) 雞蘇水, a plant which was also consumed during the Song dynasty for treating diarrhoea caused by cold diseases. ${ }^{39}$ Thanks to its medical

\footnotetext{
${ }^{35}$ Kou Zongshi 寇宗南, Bencao Yanyi 本草衍义(Beijing: Renmin weisheng chubanshe, 1990), 152.

${ }^{36}$ Chen Cheng 陳承 et al., Taiping huimin heji jufang 太平惠民和劑局方 (Beijing: Renmin weisheng chubanshe, 1985).

${ }^{37}$ Evidence of the Buddhist nature of the temple is found in a poem, which was arguably carved on the walls of the temple by Su Shi himself. It was compiled in the early nineteenth century by Shen Qinhan 沈欽韓 (1775-1831). Shen Qinhan 沈欽韓, Youxue tang shigao 幼學堂詩稿, juan 10, 27b. Scans of the copy of this compilation, held at the University of Zhejiang, available at the Chinese Text Project: http://ctext.org/library.pl? if $=$ gb\&res $=4133$.

${ }^{38}$ Su Shi 蘇軾 and 'Dongpo Quanji 東坡全集' in op. cit. (note 20), vol. 1107, 235. Ironically, the poem itself would eventually prevent Su from visiting the temple again. Months later, it was used in a defamatory way by his enemies at the court to accuse him of receiving with joy the news of Emperor Shenzhong's death. After being summoned to the court, he was sentenced to exile in Yingzhou 预州, Anhui province: Ronald C. Egan, Word, Image, and Deed in the Life of Su Shi (Cambridge, MA: Harvard University Asia Center, 1994), 102-3.

${ }^{39}$ Contemporary sources, such as Su Song's Bencao tujing, account for the medical use of betony to treat this kind of diarrhoea. Su, op. cit. (note 19), 581. This leads me to argue that the Buddhist monks in Yixing drank
} 
properties, opium poppies became a valuable drug among other Buddhist communities in Southern China. We can find evidence of this in another poem by Su Shi, entitled In reply to Abbot Bian from Nanhua Temple 答南華辯禪師. ${ }^{40}$ This poem is part of the correspondence between Su Shi and Chongbian 重辯 (?), the abbot of this temple in Shaoguan 韶關, Guangdong province. In the poem Su expresses his gratitude to the monk for the present he had sent him, which comprised salted beans 咸豆 and opium poppies, among other things. The reason for these gifts can be traced in one of Su's letters to the abbot, where Su recounts how his health had deteriorated since he moved to Huizhou, and he complained of suffering from haemorrhoids. According to $\mathrm{Wu}$ Tengxiao and Lü Liangdi, the abbot sent the beans and the poppies to prepare a recipe to alleviate Su's ailment, ${ }^{41}$ which indicates that monks at this Cantonese temple were aware that the poppy could alleviate the pain produced by haemorrhoids.

Furthermore, the sources show how the consumption of opium poppy spread to surrounding communities, where some families would prepare this decoction when visited by Buddhist monks. That was the case in Jiangxi, as shown from an even earlier poem entitled Passing by the retirement cottage of Mr. Liu 過致政屯田劉公隱盧 by Huang Tingjian 黃庭堅 (1045-1105). The poem was written in 1080, when Huang visited Liu Ningzhi 劉凝之 (1000-80) at Mount Lu, Jiangxi province. ${ }^{42}$ At the beginning of the poem, Huang mentions how the place was frequented by Buddhist monks, and how Liu's servants boiled opium poppies for them. ${ }^{43}$ Huang's poem highlights the role of casual contact in the transfer of certain dietary habits from the monastic to the lay sphere. Most probably, the consumption of opium poppy in this fashion, either for medical purposes or merely as a beverage, spread to wider communities in around the eleventh century in China.

Nevertheless, Buddhist institutions were not the only agents who played an important role in the dissemination of the medical use of opium poppy in Song-dynasty China; migrants were also important actors in this respect. For instance, Fang Shao 方勺 (1066-?) records how the use of opium poppy to treat diarrhoea had become a common practice in the twelfth century in the Huzhou area 湖州, Zhejiang province, after being introduced into the region by migrants coming from Sichuan. ${ }^{44}$ In a similar manner, certain literati were also instrumental in the transregional transfer of the medical use of opium poppy from the cloister to the countryside, as exemplified by the accounts of Su Shi's younger brother, Su Zhe 蘇轍 (1039-1112). During his visit to Mount Lu in 1080, Su Zhe became

decoctions with both plants in order to avoid diarrhoea. During the Southern Song, opium poppy would be widely applied to treat this disorder.

$40 \mathrm{Su}$, op. cit. (note 38), 348.

${ }^{41} \mathrm{Wu}$ Tengxiao 吴腾霄, 'Su Shi shidai de yingsu zhitong yaoyong 苏轼时代的罂粟止痛药用', in Tao Guangzheng 陶广正 and Liu Changhua 柳长华 (eds), Yilun jijin 医论集锦 (Beijing: Zhonghua zhongyiyao xuehui yishi wenxian fenhui), 421-4. Su visited the monastery for the first time in 1094, during his travel to Huizhou 惠州. Lü Liangdi 吕良棣, ‘Su Dongpo yu Nanhua shi 苏东坡与南华寺考证', in Qiujiang xiang zhengxie weiyuanhui 曲江县政协委员会 (eds), Qujiang wenshi ziliao xuanji, di 11 ji 曲江文史资料选辑 第 11 辑 (Qujiang, 1987), 63-74.

42 Zheng Yongxiao 郑永晓 (ed.), Huang Tingjian quanji jixiao biannian 黄庭坚全集辑校编年, vol. 1 (Nanchang: Jiangxi renmin chubanshe, 2011), 230. There is further evidence of Huang's visit to Liu's cottage in a poem, written in 1102, during his exile to Yizhou (now in Guangxi). In it, Huang praises the poem that Ouyang Xiu 歐陽修 (1007-72) had carved on the walls of the cottage to commemorate Liu's retirement from public office: ibid., 231. He had been recently appointed governor of Taihe 太和 in Jiangxi province: Lutz Bieg, 'Huang T'ing-chien', in Franke, op.cit. (note 1), 454-61.

${ }^{43}$ Huang Tingjian 黃庭堅 and Shi Rong 史容, ‘Shanggu waiji shizhu 山谷外集詩注’, in op. cit. (note 20), vol. 1114,362 .

${ }^{44}$ Fang Shao 方勺, Bozhai bian 泊宅編 (Beijing: Zhonghua shuju 1991), 109. 
acquainted with the consumption of opium poppy in Southern China as he had observed how local monks used to drink clarified butter with opium poppy seeds when reciting the sutras, as he describes in Travelling again to Mount $L u$ 再遊盧山. ${ }^{45}$ However, it was in 1104, after retiring from official service to Yingchuan, the Henanese village where the medical use of the poppy was first recorded during the Tang dynasty, that Su Zhe achieved a better understanding of the impact that the cultivation of this crop had on the economy of the local communities in Northern China. He recorded this realisation in a poem entitled Planting the seedlings of medicinal herbs 種藥苗:

Now that I have retired to Yingchuan, my house is poor and I cannot procure meat. As seasons change from summer to autumn, the turnips and the mustard are not ripe yet, which keeps my plate dull. But someone has shown me that I can mend this shortage by planting opium poppies and cassia. As many families here in Yichuan still do not know about this, I have decided to write two poems about cultivating seedlings of medicinal herbs, explaining this.

[My] gardener told me that it is possible to store the poppy. Its capsule looks like a little pot, and its seeds are small like millet. It is planted with the wheat and matures with the millet. Its seedlings survive throughout the spring and mature in the autumn. They can be ground and added to milk to cook the 'Buddhist porridge'. When old men have a weak qi, they do not eat or drink much. They cannot digest meat and do not find vegetables appetising. [Grind opium poppies] in a mortar, and boil them with water and honey. They benefit both mouth and throat and take care of lungs and stomach. After three years of reclusion, without any contact, the Buddhist hermits end up forgetting how to talk. But after drinking a cup of this beverage, they cannot help laughing with joy. Now that I have come to Yingchuan, [I do] as [I saw] on my travel to Mount Lu. ${ }^{46}$

Su Zhe's poem is probably the earliest and most informative source shedding light on the inclusion of opium poppy into Chinese agrarian economy, as well as the role of literati in the dissemination of Buddhist medical practices. The poem illustrates how certain farmers in Henan, ie. Su's gardener, were interested in the opium poppy as a crop which could be stored, although its cultivation was not widespread. ${ }^{47}$ Following his advice, Su started also to cultivate opium poppies in his allotment and encouraged other families in Yingchuan to do the same. More interestingly, the poem illustrates Su's interest in making the community aware of the medical properties of the flower for the care of the elderly, when consumed in the way of Buddhist monks, eg. the 'Buddhist porridge' 佛弹. With this poem, Su Zhe contributed to the spread of the common practice of the Buddhist monasteries of Jiangxi province into the healthcare practices of certain communities in Henan.

The recognition of the properties of opium poppy in the treatment of ailments of old age in the communities in Henan might have also been instrumental in the spread of this application of the flower to other Northern regions in China, as the below examples indicate. In the wake of the Jin invasion, which would put an end to the Song rule in Northern China, Li Fu 李復 (1052-1127) had retired to Gansu province. He found it difficult to acclimatise to the hot summers in Gansu and suffered from repeated sunstroke,

\footnotetext{
45 Su Zhe 蘇轍, Luancheng ji 欒城集 (Shanghai: Shanghai guji chubanshe, 1987), 316-17. These early contacts with Buddhist monasteries triggered in Su Zhe a keen interest in Chan Buddhism. He would later become one of the most important commentators of this branch of Buddhism during the Song Dynasty. Halperin, op. cit. (note 12), 65-71.

$46 \mathrm{Su}$, ibid., 1519-20.

47 This interest may have been result of the difficulties of the period, as local communities in eleventh-century Northern China faced cyclical famines due to bad weather, failing crops, war and the mismanagement of state grain reserves: Michael McGrath, 'The reigns of Jen-tsung (1022-63) and Ying-tsung (1063-67)', in Twitchett \& Smith, op. cit. (note 23), 291-2, 299, 307; Paul Jakov Smith, 'Shen-tsung's Reign and the New Policies of Wang An-shih, 1067-85', ibid., 418.
} 
which he wanted to treat with opium poppies, as he explains in his poem Cultivating opium poppies 種巊粟:

Last year my yang rose up severely and, red as blood, the sun dried me. ... A hot disease is consuming me after two years of suffering from sunstrokes. During the summer my internal warmth rises and I cannot stand this suffocating heat anymore. But I heard once that eating opium poppies can cleanse the heat in the stomach. Therefore, I begged my neighbours to plant this fine seed up to the point of embarrassing myself with these trivialities. ... [For this purpose] I have opened a new parcel [of land] next to my house, separated from the rest. During the spring the earth did not crack, because of the cold brought by the late snows, but the ground suddenly moved with the clear and pleasant weather, and cracks like those of the tortoise shells appeared on the surface. The sprouts burst out of the soil, fresh and green, resembling short hair. I often worried about the chrysanthemums growing next to them, and weeded them so as not to impair the poppies' growth. The recent rains moistened the soil sufficiently, and they bloom upwards in competition. Their flowers resemble peonies, red or white, they all are beautiful and pure. Their pistils fall one after another, and gradually they expose their fruit like the blue lotus. [Their fruits] are filled with grains of jade, and we harvest them with the first dew. Although I am still not sure if they will be effective to treat my disease, I am glad all the same. So, I asked my son to bring a cauldron, in which to cook them with fragrant milk. ${ }^{48}$

Li's poem illustrates the far outreach of the Southern Buddhist monasteries' practice of consuming opium poppies cooked with milk. ${ }^{49}$ Also, Li might have intended to provide future generations with some instructions as to how to set up a small poppy plantation successfully.

Further evidence of the connection between Buddhism and the consumption of opium poppy by the elderly can be found in the work of other early Southern Song scholars. In 1150, Fan Chengda 范成大 (1126-93) moved to Lin'an (nowadays Hangzhou) to prepare for the imperial examinations, after which he attained the jinshi degree in $1154 .{ }^{50}$ In some of his poems, Fan recalled those student days when he used to seek affordable accommodation in local Buddhist monasteries. In one of them, entitled Travelling alone to the small convent of Hupao Spring 獨遊虎跑泉 小菴, Fan described how the old monks of the convent cooked opium poppies and shared them. ${ }^{51}$ Also in Zhejiang, this practice spread out of its original monastic environment and reached the houses of the Buddhist followers, as shown by Cao Xun 曹勛 (1098-1174). In his poem Revisiting the times of worshiping solitude after opting for a simple life devoted to service 選上人素履精修仆先識於崇信岑 寂之時重來見, Cao describes how he visited his master, Song Zhikong 松竹空, at Mount Chicheng 赤城山. Now elderly, Song, who was a devout Buddhist himself, used to drink an opium poppy beverage when resting:

In the beginning of my travels I went to Chicheng, to Mr. Song Zhikong's. These days the master reveres the Buddhas and does not spare the slightest expense in his offerings. ... The hanging scrolls comforted his old eyes, and he ate an opium poppy decoction at night. ${ }^{52}$

Similarly to the case illustrated in Su Zhe's poems, the poppy was integrated into the local diet of the communities settled along the basin of the Yang-tze River as result of the spread of these habits from Buddhist monasteries. That was the case in Anhui

${ }^{48} \mathrm{Li} \mathrm{Fu}$ 李复 (s.f.): «Yushui ji 潏水集», in op. cit. (note 20), vol. 1121, 104.

49 Ibid., 1-2. Lu Xinyuan 陸心源, Songshi yi 宋史翼 (Taipei: Wenhai chubanshe, 1967), 373-6.

${ }^{50}$ Peng Wanglong 彭万隆 and Xiao Ruifeng 肖瑞峰 (eds), Xihu wenxue shi: tang song quan 西湖文学史 : 唐 宋卷 (Hangzhou: Zhejiang daxue chubanshe, 2013), 224-5.

${ }^{51}$ Fan Chengda 范成大, 'Shihu jusi shiji 石湖居士詩集', in op. cit. (note 20), vol. 1159, 613. This poem was written most probably in the period between Cao's retirement from public office at Mt Tiantai in 1142 and before his return to the court in 1169. Julia K. Murray, Mirror of Morality: Chinese Narrative Illustration and Confucian Ideology (Honolulu: University of Hawaii Press, 2007), 83.

52 Cao Xun 曹勛, ‘Songyin Ji 松隱集’, in op. cit. (note 20), vol. 1129, 368. 
province, as recorded in the poems by Zhou Zizhi 周紫芝 (1082-1155). Zhou was living in Xuancheng 宣城, Huai-nan region 淮南, close to the border between the Song and Jin, and in his poems he depicts the harsh conditions of life in this war-torn region. ${ }^{53}$ In one of these poems, The poppy has ripened 貣粟將成, Zhou describes how the flower started to be considered a sign of good fortune among those families that were particularly hit by famine:

At Mr. Yu's house, nine of ten meals have no meat and his reserves of grain are not sufficient, but the morning brings a sudden wealth to his children, as many poppies, ripe with seeds, grow by the wall of his house. This makes the flowers more beautiful to them than the finest brocade. As they see the poppies, they turn the cauldron around and start cooking them. They drink once and the clarified butter brings their mouths to life; they drink again and an evening mist covers their morning hunger. Although its taste may seem bland, its fruit is precious, and its warmth may help restore old Gan's spleen. ${ }^{54}$

This poem reflects the increasing importance of opium poppy as a crop among poor families in Anhui. It also indicates its use to treat digestive ailments in the elderly. These families consumed poppies with clarified butter, as did the Buddhist monk in Mount Lu. In another poem, Cultivating poppies 種罌粟, Zhou gives further indication of this connection. This poem recounts how Zhou had a little allotment next to his house, where he considered planting bamboo in order to procure some wood to build an extension for his house. However, while consulting on this option with a local farmer, the old man laughed at him for his ambitious plans and advised Zhou to plant opium poppies instead. In the farmer's opinion, while bamboo would take years to grow big enough to use, opium poppies would grow in just a few months and could provide seeds that could be cooked with clarified butter to produce 'monks' porridge' 僧粥. ${ }^{55}$

Eventually, the literati of the period show how local communities in Southern China included opium poppy into their diet also for recreational purposes. In Linchuan county 臨川, Jiangxi province, a local scholar called Xie Ke 謝薖 (1074-1116) wrote a poem praising the bittersweet flavour of a 'poppy decoction' 覞粟湯. ${ }^{56}$ Likewise, later literati, such as Li Mixun 李彌遜 (1090-1153) and Hong Shi 洪适 (1117-84), also comment on the spread of this drink in Fujian and Jiangnan. ${ }^{57}$ These poems show that the existence of local Buddhist monasteries where opium poppies were consumed in this fashion may have been instrumental in the integration of the poppy in the gastronomy of the Yang-tze river basin. Equally, the poem entitled Jiong asked me to compose a poem for his jujube beverage 垌請作霖飲詩 by Wu Zeli 吳則禮 (?-1121) notes how opium poppies were used to make a local variety of tofu. ${ }^{58}$ In certain cases, such gastronomic incorporations may have also had medical underpinnings. In his poem entitled Perilla 紫蘇, Zhan Fu 章 甫 (?-c.1185) describes how the consumption of certain snacks helped villagers to keep healthy, particularly those who could not afford proper medical care. One of the snacks

${ }^{53}$ Ren Qun 任群, Zhou Zizhi nianpu 周紫芝年谱 (Xi'an: Shijie tushu chuban Xi' an youxian gongsi, 2014),1-4. Tao Jing-Shen, 'The move to the south and the reign of Kao-tsung (1127-1162)', in Twitchett \&. Smith, op. cit. (note 23), 697-703.

54 Zhou Zizhi 周紫芝, ‘Taicang timi ji 太倉稊米集’, op. cit. (note 20), vol. 1141, 198-9.

55 Ibid., 150.

56 Xie Ke 謝薖, 'Zhi You Ji 竹友集', in ibid., vol. 1122, 583.

${ }^{57}$ Li Mixun 李彌遜, 'Yunxi ji 筷溪集', in ibid., vol. 1130, 733. Hong Shi 洪适, 'Panzhou wenji 盤洲文集', in ibid., vol. 1158, 304 .

${ }^{58}$ Wu Zeli 吳則禮, 'Beihu ji 湖居集', in ibid., vol. 1122, 435. Wu composed most of the poems compiled in Beihu ji between 1106 and 1114. During that period Wu was the governor of Runzhou 潤州 and Xuyi county 䀒眙, both in Jiangsu province. Yue Guiming 戀貴明, Siku jiben bieji shiyi 四庫輯本别集拾遺 (Beijing: Zhonghua shuju, 1983), 593. 
mentioned by Zhan in the poem is a mixture of tofu with opium poppy seeds, ginger and honey. ${ }^{59}$ Zhan's poem sheds light on the way in which diet and medicine were intertwined in daily healthcare in Southern Song-dynasty China, and how opium poppy found its place in the local diet because of its medical properties.

The testimonies by literati from late eleventh- and early twelfth-century China illustrate how medicinal practices, such as the prophylactic consumption of opium poppy among the elderly, could be transferred across different social groups, both religious and secular. From the above examples, it becomes clear that various communities across China incorporated opium poppy into their diet when in contact with different Buddhist individuals or institutions. Such dissemination would in turn lead to important changes in medicinal applications of the poppy during the Southern Song dynasty, ie. a shift towards its application in the treatment of diarrhoea and coughing.

\section{The Assimilation of Opium Poppy into Scholarly Medical Practice during the Southern Song Dynasty (1127-1279)}

Early twelfth-century medical sources also account for how the Buddhist use of opium poppy started to have an impact on medical practice in China. They show how practitioners of the time changed their use of opium poppy after encountering its application by Buddhist monks, although not all the practitioners of the period were exposed to this influence. It would appear that some doctors in the North continued utilising the flower as recommended in early Song materia medica, such as Wang Kuang 王貺 (?), whose Quansheng zhimi fang 全生指迷方 [Formulae for Guiding the Lost throughout Life] recorded two recipes including opium poppy: one to treat xiaoke 消渴, and the other describing the opium poppy beverage 罌粟湯, which he included in the section about the diseases of the spleen 脾證. ${ }^{60}$ In the second recipe, Wang praised the miraculous properties of this concoction to treat patients who had 'lost strength in one leg from the knee to the foot, which become gradually leaner as the muscle lacks lustre'一邊足膝無力, 漸漸瘦 細，肌肉不澤。

Conversely, some physicians coming from the South learnt about the medicinal applications of the poppy from Buddhist monks and incorporated it into their practice. In his first formulary, Puji benshi fang 普濟本事方 [Fact-based Formulae for Common Remedies], published around 1132, a southern physician, Xu Shuwei 許叔微 (10791154), recounts how he became acquainted with the medical use of the poppy thanks to a Buddhist monk, who gave him a recipe for 'costus powder' 木香散. The recipe required half a tael of opium poppies and, according to the monk, it was used by the people in Fujian to treat those affected by bloody free-flux disease 血痢. ${ }^{61}$ Later in his life, $\mathrm{Xu}$ published an extended version of this treatise, entitled Leizheng puji benshi fang suji 類証普濟本 事方續集 [Assorted Extension to Fact-based Recipes for Common Remedies]. This work shows how, after observing the effects of the opium poppy, Xu expanded its use to create formulae for the treatment of intestinal ailments which involved diarrhoea, ie. different types of the free-flux disease 痢疾, such as red and white free-flux disease 赤白痢疾, as well as abdominal pain 腹痛, diarrhoea with blood 瀉血 or intestinal bleeding 大腸出血. ${ }^{62}$

${ }^{59} \mathrm{Zhan} \mathrm{Fu}$ 章甫, in op. cit. (note 20), vol. 1165, 390.

${ }^{60}$ Wang Kuang 王貺, Quansheng zhimi fang 全生指迷方 (Beijing: Renmin weisheng chubanshe, 1986), 44, 73.

${ }^{61}$ Xu Shuwei 許叔微, Puji benshi fang 普濟本事方 (Shanghai: Shanghai kexue jishu chubanshe, 1978), 56.

${ }^{62} \mathrm{Xu}$ Shuwei 許叔微, 'Leizheng puji benshi fang suji 類証普濟本事方續集’, in Cao Hongxin 曹洪欣 (ed.),

Haiwai huigui zhongyi guji shanben jicui 海外回歸中醫古籍善本集粹, vol. 19 (Beijing: Zhongguo guji 
Therefore, Xu's work provides us with evidence of how Buddhist monks informed the practice of Chinese physicians during the Southern Song dynasty, by allowing them to develop novel medical applications for the flower. In addition, other instances of such Buddhist connection to the medical use of opium poppy are traceable in late twelfthcentury Jiangxi, where doctors like Hong Zun 洪遵 (1120-74) prescribed recipes such as the Guanyin powder 觀音散 in order to treat minor digestive ailments that may have caused lack of appetite and fatigue 理脾胃不和, 氣弱昏倦, 多困, 不思食. ${ }^{63}$

Other early-twelfth-century sources also show how the transmission of the medical use of the poppy by southern monks, carried on by officials like Su Zhe, may have prompted changes in its application by scholarly practitioners from the North. Living in Henan province since the 1110 s, Zhang Rui 張鋭 (?) compiled a formulary entitled Jifeng puji fang 雞峰普濟方 [Formulae of common recipes from Jifeng], which was published around 1133. The treatise shows Zhang's distrust towards traditional formulae and his keen interest in developing new remedies; an attitude which allowed him to record the shift in the medicinal application of opium poppy. Zhang compiled eight recipes containing opium poppy in this treatise. Of these, only two had a more traditional use, one for bleeding in patients with huangdan 黄㾝 and one for xiaoke 消渴. The other six remedies show a use of opium poppy more in line with that developed by Xu Shuwei, utilising it the treatment of ailments related to diarrhoea, such as bloody free-flux disease 血痢, red and white freeflux disease 赤白痢, and outflow with free-flux disease 瀉痢, as well as abdominal pain 腹痛. ${ }^{64}$ The progression towards this new use seemed to carry on even after the conquest of Northern China by the Jurchen of the Jin dynasty, as recorded in the work of Liu Wansu 劉完素 (1110-1200), who included eight formulae with opium poppies in Huangdi suwen xianming lunfang 黃帝素問宣明論方 [Treatises and Formulae for the Dissemination of the Yellow Emperor's Basic Questions]. Liu designed these remedies to treat diarrhoea, coughing and pain in chest or muscles, and does not comment on its use in the treatment of huangdan 黄疸 or xiaoke 消渴. ${ }^{65}$

Other practitioners of the period even managed to understand the possible contraindications of the flower as a medicine and developed ways to prevent them. Living in Zhejiang contemporarily to Lu You, Wang Shuo 王碩 (?) compiled, in Yijian Fang 易簡方 [Formulae of Simple Remedies], two recipes including opium poppy: one for an 'almond decoction' 杏子湯, prescribed to treat severe coughing, and one for a 'decoction to cut defecation'斷下湯 indicated in the treatment of dysentery and several types of diarrhoea. ${ }^{66}$ In both recipes, Wang warned that the opium poppy is very astringent, a reason why it should be added to these recipes only if the condition of the digestive organs of the patient was 'robust' 實 enough, and should be completely avoided when the patient was feeling nauseous. The work of Wang Shuo seems to have been particularly influential, as it had a direct impact on the use of opium poppy by other contemporary practitioners, such as Yan Yonghe 嚴用和 (?-c.1267), who copied Wang's warning about the nature of the

chubanshe, 2005), 108-11, 114-15, 139-40. Zhibin Zhang and Paul Unschuld, Dictionary of the Ben Cao Gang Mu, Volume 1: Chinese Historical Illness Terminology (Oakland: University of California Press, 2015), $312,315$.

${ }^{63}$ Hong Zun 洪遵, ‘Hongshi jiyan fang 洪氏集驗方', in Songren yifang sanzhong 宋人醫方三重 (Shanghai: Shangwu yinshuguan chuban, 1955), 69-70.

${ }^{64}$ Zhang Tuo 張鋭, Jifeng puji fang 雞峰普濟方 (Shanghai: Shaghai kexue jishu chubanshe, 1987), 93, 160, $163,165,175-7,263$.

${ }^{65}$ Liu Wansu 劉完素, ‘Huangdi suwen xianming lunfang 黃帝素問宣明論方’, in Liu Shouzhen 劉守真 (ed.), Hejian yi ji 河間醫集 (Beijing: Renmin weisheng chubanshe, 1998), 235, 281-2, 286-7, 294.

${ }^{66}$ Wang Shuo 王碩, Yijian Fang 易簡方 (Beijing: Renmin Weisheng Chubanshe, 1995), 25, 32-3. 
flower in Yanshi jisheng fang 嚴氏濟生方 [Formulae for the Benefit of Life by Mr. Yan]. ${ }^{67}$ As result of the improvement in the understanding of the properties of opium poppy since the 1120s, the flower appeared consistently in Southern Song formularies mainly to treat dysentery and coughing, as shown in the works of Chen Yan 陳言 (?), Wang Zhizhong 王執中 (c.1140-1207), Zhang Gao 张杲 (1149-1227) or Yang Shiying 楊士瀛 (?), who would even consider it as an essential ingredient in the preparation of remedies to treat free-flux illness in patients with malaria 瘧痢. ${ }^{6}$

Furthermore, the inclusion of opium poppy in Southern Song medical literature also allowed more developments in its application. In the late twelfth century, Chinese doctors started to utilise it to treat more specific ailments, such as coughing with panting 咳嗽喘急. In fact, such applications started in the North, in the area controlled by the Jin dynasty, as shown in the work of Liu Wansu. ${ }^{69}$ In the late 1170 s, the practice seemed to have crossed the border and informed the practice of doctors such as Yang Tan 楊倓 (1120 85), Wu Yankui 吳彦筫 (1117-?) and Liu Xinfu 劉信甫 (?), standardising this particular application of opium poppy into a common medicinal use. ${ }^{70}$ An additional indication of these changes can be seen in the incorporation of the poppy into paediatrics. This process started in the early twelfth century, as shown in Youyou xinshu 幼幼新書 [New Book of Paediatrics] by Liu Fang 劉昉 (?-1150), the most important medical treatise on paediatrics from the Song dynasty and which included eleven recipes to treat free-flux disease and coughing. ${ }^{71}$ Such integration is also shown in other paediatric treatises of the period, such as Xiao'er weisheng zongwei lunfang 小兒衛生總微論方 [Comprehensive and Subtle Treatises and Formulae for Children's Healthcare] by He Daren 何大任, or Chanbao zhufang 産寶諸方 [Various Formulae of Obstetrics], and in the work of physicians such as Yang Tan. ${ }^{72}$ Perhaps as result of its application in the field of paediatrics, the poppy was also introduced into late Song gynaecological practice. Chen Ziming 陳自明 (1190-1270), the master of gynaecology 婦科 in Song dynasty China, ${ }^{73}$ compiled eight recipes including opium poppy to treat free-flux disease, diarrhoea, coughing and panting, in Furen daquan liangfang 婦人大全良方 [Great Compilation ofGynaecological Formulae], eight recipes including opium poppy to treat free-flux disease, diarrhoea, coughing and panting. ${ }^{74}$

${ }^{67}$ Yan Yonghe 嚴用和, 'Yanshi jisheng fang 嚴氏濟生方', in Cao, op. cit. (note 62), 88-9.

${ }^{68}$ Chen Yan 陳言, Sanyin jiyi bingzheng fanglun 三因極一病証方論 (Beijing: Renmin weisheng chubanshe, 1963), 96, 162-3, 172-3, 267. Wang Zhizhong 王執中, Zhenjiu shengjing 針炎資生經 (Beijing: Zhongguo Shudian, 1987), juan 3, 38b-39b. Zhang Gao 張某, 'Yi shuo 醫説', in Qiu Peiran 求沛然 (ed.), Zhonguo yixue dacheng sanbian 中國醫學大成三編, vol. 12 (Shanghai: Yuelu sushe, 1994), 109-10. Yang Shiying 楊士瀛, 'Renzhai zhizhi 仁齋直指', in op.cit. (note 20), vol. 744, 33.

${ }^{69}$ Liu Wansu op. cit. (note 65), 284-5.

70 Yang Tan 楊倓, Yang shi jiacang fang 楊氏家藏方 (Beijing: Renmin weisheng chubanshe, 1988), 163-4. Wu Yankui 吳彦龍, 'Chuanxin Shiyong fang 傳信適用方', in op. cit. (note 20), vol. 741, 759-60. Liu Xinfu 劉信甫, ‘Huoren shizheng fang houji 活人事證方後集', in Li Kexia 李克夏, Li Yuqing 李玉清 (eds), Huoren shizheng fang houji. Qianjin baoyao 活人事证方后集. 千金宝要 (Shanghai: Shanghai kexue jishu chubanshe, 2003), 107.

${ }^{71}$ Liu Fang 劉昉, 'Youyou xinshu 幼幼新書', in Cao, op. cit., (note 62), vols. 13-17, 2820-1, 3101-3, 4143-4, 4260, 4297, 4322-3, 4445, 4453-4, 4463-4.

72 He Daren 何大任, Xiao'er weisheng zongwei lunfang 小兒衛生總微論 (Shanghai: Shanghai kexue jishu chubanshe, 1959), 38-9, 130, 133-4, 141, 145, 147-8. 'Chanbao zhufang 産寶諸方', in Qiu Peiran 求沛然 (ed.), Zhonguo yixue dacheng xubian 中國醫學大成續編, vol. 9 (Shanghai: Yuelu sushe, 1992), 32. Yang, op. cit. (note 68), 371.

73 Charlotte Furth, A Flourishing Yin: Gender in China's Medical History: 960-1665 (Berkeley: University California Press, 1999), 70.

${ }^{74}$ Chen Ziming 陳自明, Furen daquan liangfang 婦人大全良方 (Beijing: Renmin weisheng chubanshe, 1992), $182-4,260,264-7,554$. 
A geographical survey of the use of opium poppy is also relevant to the argument raised in this paper. While most of the formularies of the period do not provide much information on the geographical origin of the recipes, a handful of the sources that do provide the location where their compilers found such formulae indicate the close relationship between Buddhism and the use of opium poppy. Judging from the number of mentions of the poppy in these sources, opium poppy was mostly used in the Jiangxi region. There, doctors such as Liu Fang and Wu Yankui 吳彦嗄 (1117-?) compiled ten recipes including opium poppy, which were used by local practitioners in cities such as Fuzhou 撫州 and Nanchang 南昌. ${ }^{75}$ Liu Fang documented its use in four recipes by local doctors from Yuezhou 岳州 and Changsha 長沙, in Hunan; ${ }^{76}$ Liu Xinfu found one practitioner using it in Wuchang 武昌, in Hubei; ${ }^{77}$ while Wang Qiu 王璆 (?) recorded three recipes including opium poppy in Zhejiang and Anhui. ${ }^{78}$ These sources indicate that local doctors developed a wider use of opium poppy in the regions with important Buddhist centres, such as Jiangxi, where the monasteries at Mount Lu were located.

Finally, this change in the medicinal use of the poppy during the Southern Song dynasty would impact the official perspective on the flower. In the official pharmacopeia Shaoxing bencao 紹興本草 [Materia Medica of the Shaoxing Era], published in 1157, the departure from early Song official materia medica became evident. Although this work mentions the use of opium poppy to treat cinnabar poisoning, as mentioned in Kaibo bencao, it also warns that such an application does not have any solid basis to rely on. Instead, this materia medica records how cooked opium poppies were included in many recipes to treat diarrhoea, due to its astringent nature and availability. ${ }^{79}$ Almost one century later, yet another official materia medica, Baoqing bencao zhezhong 寶慶本草折衷 [Balanced Summary of the Materia Medica of the Baoqing Era], gives an indication of this trend. Its editor, the court physician Chen Yan 陳衍 (1190-1257), updated the entry about opium poppy by restricting its use to the treatment of diarrhoea and coughing, also warning about its astringent nature and the risks of vomiting. ${ }^{80}$ However, no other source shows this process as clearly as the official formulary of the Song court, Taiping huimin heji jufang. In the extension to this formulary, which was compiled in the late twelfth century by an obscure official of the time called Wu Ting 吳珽 (?), ${ }^{81}$ opium poppy appears as an ingredient in five recipes to treat the aforementioned ailments. It would also appear in seven new recipes added in two other extensions to the formulary: four in Baoqing xinzeng fang 寶慶新增方 [Formulae Newly Added in the Baoqing Era], compiled c.1227, and three in Xutian zhuju jingyan mifang 續添諸局經驗秘方 [Addition of Secret Formulae Developed from the Experience of Several doctors in the Imperial Pharmacy], compiled around $1252 .{ }^{82}$ These sources illustrate that the interest of court chemists in opium poppy

\footnotetext{
${ }^{75}$ Liu, op. cit. (note 71), 3103, 4143-4, 4453-4. Wu, op. cit. (note 70), 759-64, 797-8.

${ }^{76}$ Liu, op. cit. (note 71), 4129-30, 4260, 4297, 4463-4.

${ }^{77}$ Liu, op. cit. (note 70), 100.

${ }^{78}$ Wang Qiu 王璆, ‘Shizhai baiyi xuanfang 是齋百一選方’, in Qiu Peiran 或沛然 (ed.), Zhongguo yixue dacheng sanbian 中國醫學大成三編, vol. 4 (Changsha: Yuelu shushe, 1994), 557-8.

${ }^{79}$ Wang Jixian 王繼先 et al., Shaoxing bencao xiaozhu 绍兴本草校注 (Beijing Zhongyi guji chubanshe, 2007), 309.

${ }^{80}$ Chen Han 陳衍, ‘Baoqing bencao zhezhong 寶慶本草折衷’, in Zheng Jisheng 郑金生 (ed.), Nansong zhenxi bencao sanzhong 南宋珍稀本草三种 (Beijing: Renmin weisheng chubanshe, 2007), 614.

${ }^{81}$ Xiao Yongzhi and Zheng Jinsheng dated the publication of this extension to Taiping huimin heji jufang in the late twelfth century. Xiao Yongzhi 蕭永芝 and Zheng Jinsheng 鄭金生, 'Yingyin shouming 影印説明’, in Chen, op. cit. (note 36), 3-4.

${ }^{82}$ Ibid., 146-7, 152-3, 232-3, 237, 239, 241-3.
} 
only appeared after local doctors had refined their use of the flower, prompting the shift in its medical application in China.

\section{Conclusions}

This paper examined the role of non-medical actors, such as Buddhist institutions and literati, in the assimilation of the medical use of opium poppy in Song-dynasty China. By doing so, it highlighted the role of Buddhist actors in the development of Chinese medicine during the Song. After being introduced into China during the Tang dynasty, opium poppy started to be consumed and used for medical purposes during the Five Dynasties and Ten Kingdoms period as result of certain Buddhist influences. Since then, the poppy was included in the official medical treatises of the early Song dynasty, as a component in remedies to treat disorders such as xiaoke and huangdan, as well as cinnabar poisoning. However, Southern Song medical literature shows how such use was gradually replaced by the application of the flower to cure diarrhoea, coughing and spams. This shift in the medical use of the poppy seems to have originated from the Buddhist monasteries of Southern China, as shown in the work of several literati of the late Northern Song dynasty. The accounts of these authors reflect how Buddhist monks in Southern China consumed opium poppy and used it prophylactically against diarrhoea. These sources also indicate how the presence of Buddhist monasteries facilitated a gradual inclusion of the poppy into the diet of several communities around Buddhist temples in Mt Lu, Mt Chicheng and Anhui province. Some of these literati seem also to have been instrumental in the transmission of the medical use of opium poppy to Henan or Gansu, disseminating these Buddhist practices through Northern China. Eventually, the spread of these practices outside of Buddhist monasteries had an impact on the praxis of twelfth-century physicians, such as $\mathrm{Xu}$ Shuwei; one which contributed to a fundamental change in the medical use of opium poppy during the Southern Song dynasty.

With this research, I have shed light on the process of assimilation of opium poppy in medical practice during the Song dynasty. By doing so, this paper also contributes to our understanding of the development of Chinese medicine in medieval times. In terms of theory, it has reassessed the role of Buddhist medical practices in the development of Chinese medicine during the Song dynasty. Using opium poppy as a case study, I have illustrated how healthcare practices in Buddhist monasteries had an impact on secular medicine during the Song period. Practices such as the use of opium poppy to prevent diarrhoea, or its application in healthcare of the elderly, emanating from Buddhist monasteries influenced medical practitioners and local communities around them. Eventually, the spread of these customs contributed to new developments in the medical use of the plant in China; a change which would even reach the official medical literature, as shown in the materia medica from the late Southern Song dynasty. Finally, regarding methodology, this paper emphasised the relevance of non-medical sources in the study of certain developments in premodern Chinese medicine. By taking into consideration the work of the literati of the time, this paper has unveiled the profound impact exerted by Buddhist medical practices on the evolution of the medical use of opium poppy among both the practitioners and layfolk. Therefore, this study shows the potential of these sources to describe both professional and nonprofessional healthcare in premodern China. 